\title{
Floral Biology of Some Minor Fruits of Assam
}

\author{
Nishita Pathak ${ }^{1 *}$, Rajendra Prasad Das, Utpal Kotoky and Swosti Dedapriya Behera \\ Department of Horticulture, Assam Agricultural University, Jorhat-785013, Assam, India \\ *Corresponding author
}

\begin{abstract}
A B S T R A C T
An investigation was carried out to study the Floral biology of five different minor fruit species of Assam viz., 'Mirika-tenga' (Parameria polyneura Hk.f.), 'Bogi jamuk'

\section{Keywords}

Floral biology, Minor fruits, Assam

Article Info

Accepted:

08 June 2018

Available Online:

10 July 2018 (Syzygium jambos (L.) Alston), 'Ou-tenga' (Dillenia indica L.), 'Amora' (Spondias mangifera) and 'Poniol' (Flacourtia jangomas (Lour.) Raeus.) belonging to different families. In Parameria polyneura flowering started from $21^{\text {th }}$ December to $16^{\text {th }}$ January with a duration of 27 days; in Syzygium jambos from $20^{\text {th }}$ December to $12^{\text {th }}$ April with a duration of 115 days; in Dillenia indica from $21^{\text {st }}$ June to $11^{\text {th }}$ July with a duration of 21 days; in Spondias mangifera from $15^{\text {th }}$ march to $6^{\text {th }}$ April with a duration of 23 days and in Flacourtia jangomas from $30^{\text {th }}$ march to $16^{\text {th }}$ April with a duration of 18 days. Among the five fruits Dillenia indica had the largest sepal and petal whereas Spondias mangifera had the smallest petal and Flacourtia jangamos had the smallest sepal. In Parameria polyneura number of sepals was recorded 4 and was devoid of petals, in Syzygium jambos 4 sepals and 4 petals, in Dillenia indica 5 sepals and 5petals, in Spondias mangifera 5 sepals and 5 petals and Flacourtia jangomas flower was devoid of petals and consisted of 5-6 sepals.
\end{abstract}

\section{Introduction}

Wild fruits are the valuable source of food for mankind since the dawn of civilization. Prehistoric man in the forest depended on these fruits and they passed on important information on the choice and use of wild fruit species from generation to generation. As a result, present day horticulture came into existence (Singh et al., 2000). Some of the semi-wild fruits grown in different areas that have been domesticated but not cultivated in commercial scale are called as minor fruits. Minor fruits are usually not extensively cultivated and their consumption and trade being more limited both geographically and quantitatively, although many are of considerable economic importance in their respective regional markets for nutritive value and medicinal use. These fruit crops require less care for successful cultivation as they are hardy in nature (Sauco, 2008). Some of these species are well adapted to marginal land with low cost inputs, may though be of great benefit for the survival of poor communities and sustainability of agricultural ecosystems. Assam is a unique gift for production of a large number of minor fruit crops of tropical, 
sub tropical and temperate origin. Moreover, the warm and humid climate of this region is unique to grow these fruits. In Assam a number of minor fruits are in existence like 'Poniol' (Flacourtia jangomas); 'Bogi Jamuk' (Syzygium jambos); 'Ou-tenga' (Dillenia indica); 'Amora' (Spondias mangifera); 'Mirika-tenga' (Parameria polyneura) etc. Minor fruits play a key role in human diet of the rural people of Assam. Among the minor fruits of this region, some are good source of vitamins and minerals. As reported by Kermasha et al., (1987) the protein and vitamin C content of 'Poniol' (Flacourtia gangomos) is more than 10 times higher than apples. This fruit is rich in calcium and may be considered as good source of calcium particularly in developing countries where milk and milk products are in short supply. 'Ou-tenga' (Dillenia indica) also contains a considerable amount of calcium and phosphorus (Gopalan et al., 1971).

'Bagi Jamuk' also known as Rose Apple has shown to prevent the development of cancer of the prostate. Rose apple are usually loaded with vitamin $\mathrm{C}$ and also fibre, a substance which has proven to reduce cholesterol levels. The fruit is recognized as a tonic for the brain and also liver. 'Amora' also known as Hog plum also have many medicinal values. Different fruits of this region are harvested in different seasons of the year. Thus, the indigenous minor fruits are meeting the demand of vitamins and minerals of the people of this region from long past. The added advantages to cultivation of these unusual indigenous minor fruits can be pinpointed as having relatively wider phonological and soil adaptability, higher degree of pest and disease resistance and minimal demand for intensive production care as compared with the major fruits. These minor fruits are still in wild and semi-wild form and their cultural and nutritive values are yet to standardise. Keeping these facts in view, an investigation was carried out to study the floral biology of the following minor fruits of Assam - like Elephant apple (Ou-tenga), Rose apple (Bagi jamuk), Hog plum (Amora), Governors plum (Ponial), Spotted plum (Mirika-tenga). As the study of the floral biology will be helpful in carrying out the crop improvement programme of these minor fruits.

\section{Materials and Methods}

The study was carried out from 2014 to 2016 and five different minor fruits viz., 'Mirikatenga' (Parameria polyneura Hk.f.), 'Bogi jamuk' (Syzygium jambos (L.) Alston), 'Outenga' (Dillenia indica L.), 'Amora' (Spondias mangifera) and 'Poniol' (Flacourtia jangomas (Lour.) Raeus.) were selected for the study. One number of bearing trees showing uniform growth, vigour with good bearing condition were selected for the study for each species in Jorhat district. Flowers of each fruits were collected and brought to the laboratory for study. The time of flowering of the plant was observed in days of the month in which flowering appeared in the studied fruits and was recorded. The duration of flowering was recorded in days i.e. date for the first to last flower appearance. The number of sepals and petals per flower was counted and recorded. For size of the sepals and petals, length and breadth of five sepal and five petal were measured using a scale, mean was calculated and expressed in centimetres. The shape of the sepal and petal was determined by visual observation. The androecium character i.e. number of anthers, colour of anthers, number of filaments, colour of filaments and attachment of anthers to the filaments were closely observed and measured. The gynoecium character i.e. number of style, colour of style, type of style, number of ovary and type of ovary were closely observed and measured. 


\section{Results and Discussion}

\section{Time and duration of flowering}

The results obtained after the study of time and duration of flowering of the five minor fruits are presented in Table 1. The flowering time of Parameria polyneura started from mid-December to mid-January i.e. flowering was observed from $21^{\text {th }}$ December and lasted till $16^{\text {th }}$ January with a duration of flowering of 27 days. The peak flowering time was seen between $22^{\text {nd }}$ December to $28^{\text {th }}$ December. Similar result was reported by Neog (1990) and Barua (2015). In Syzygium jambos flowering started from mid-December to $2^{\text {nd }}$ week of April i.e. flowering was observed from $20^{\text {th }}$ December to $12^{\text {th }}$ April with a duration of 115 days. Similar result was reported by Tarai et al., (2006), Tarai and Kundu (2008) and Barua (2015). In case of Dillenia indica flowering started from late June and lasted till the $2^{\text {nd }}$ week of July i.e. from $21^{\text {st }}$ June to $11^{\text {th }}$ July with a duration of flowering of 21 days. In 2015 Barua (2015) reported that Dillenia indica flowers from $19^{\text {th }}$ June till $10^{\text {th }}$ July with a duration of 22 days and Neog (1990) also reported that Dillenia indica flowers in between last week of june to third week of July with a duration of 20 days. Neog and Mohan (1993) reported that Dillenia indica flowers in the month of June-July (2015). In Spondias mangifera it started from mid-march to first week of April i.e. from $18^{\text {th }}$ march and $2^{\text {nd }}$ April with a duration of 23 days and in case of Flacourtia jangamos flowering started from last week of March to second week of April i.e. flowering was observed from $30^{\text {th }}$ march to $16^{\text {th }}$ April with a duration of 18 days. The peak flowering time was observed from $3^{\text {rd }}$ April to $10^{\text {th }}$ April. The present result was in agreement with Sarma (1989) but Barua (2015) reported a higher duration of 25 days.

\section{Number of sepals and petals}

Data presented in Table 2 shows the number sepals and petals present in the flowers of the respective minor fruits. The study showed that Parameria polyneura and Flacourtia jangamos are devoid of petals.

\section{Size of sepals and petals}

The study revealed that there was a significant difference in the size the sepals and petals of the five fruits. Among the five fruits Dillenia indica had the largest sepal and petal whereas Spondias mangifera had the smallest petal and Flacourtia jangamos had the smallest sepal. The data's regarding the size of sepals and petals in terms of length and breadth of each fruits is presented in Table 3, 4, 5, 6, 7 respectively.

\section{Shape of sepals and petals}

Study revealed significant difference in the shape of the sepals and petals of the flowers of each species of fruit. The flower of Parameria polyneura was observed to be four lobed with a single perianth. The flower was tubular from the base differentiated into four distinct parts on the upper portion, which were triangular to ovate in shape considered as the sepals.

Table.1 Time and duration of flowering

\begin{tabular}{|l|l|l|}
\hline Name of the minor fruits & \multicolumn{1}{|c|}{ Time of flowering } & \multicolumn{1}{c|}{ Duration of flowering } \\
\hline Parameria polyneura & from mid-December to mid-January & 27 days \\
\hline Syzygium jambos & from mid-December to 2 ${ }^{\text {nd }}$ week of April & 115 days \\
\hline Dillenia indica & from late June to 2 $2^{\text {nd }}$ week of July & 21 days \\
\hline Spondias mangifera & from mid-march to first week of April & 23 days \\
\hline Flacourtia jangamos & last week of March to second week of April & 18 days \\
\hline
\end{tabular}


Table.2. Number of sepals and petals

\begin{tabular}{|l|c|c|}
\hline Name of the minor fruits & Number of sepals & Number of petals \\
\hline Parameria polyneura & 4 & - \\
\hline Syzygium jambos & 4 & 4 \\
\hline Dillenia indica & 5 & 5 \\
\hline Spondias mangifera & 5 & 5 \\
\hline Flacourtia jangamos & $5-6$ & - \\
\hline
\end{tabular}

Table.3 Sepal size of Parameria polyneura

\begin{tabular}{|l|l|l|}
\hline Flowers & Sepal length $(\mathbf{c m})$ & Sepal breadth $(\mathbf{c m})$ \\
\hline F-1 & 0.29 & 0.20 \\
\hline F-2 & 0.29 & 0.18 \\
\hline F-3 & $\mathbf{0 . 3}$ & $\mathbf{0 . 2 0}$ \\
\hline F-4 & 0.29 & 0.19 \\
\hline F-5 & 0.3 & 0.20 \\
\hline Mean & $\mathbf{0 . 2 9}$ & $\mathbf{0 . 1 9}$ \\
\hline
\end{tabular}

Table.4 Sepal and Petal size of Syzygium jambos

\begin{tabular}{|l|l|l|l|l|}
\hline Flowers & Petal length $(\mathbf{c m})$ & Petal breadth $(\mathbf{c m})$ & Sepal length $(\mathbf{c m})$ & Sepal breadth $(\mathbf{c m})$ \\
\hline F-1 & 1.9 & $\mathbf{1 . 2}$ & 0.7 & 1.3 \\
\hline F-2 & 1.9 & 1.19 & $\mathbf{0 . 7 3}$ & 1.31 \\
\hline F-3 & 1.85 & 1.18 & 0.71 & 1.3 \\
\hline F-4 & 1.87 & 1.18 & 0.7 & $\mathbf{1 . 2 9}$ \\
\hline F-5 & $\mathbf{1 . 9 1}$ & 1.2 & 0.72 & 1.3 \\
\hline Mean & $\mathbf{1 . 8 8}$ & $\mathbf{1 . 1 9}$ & $\mathbf{0 . 7 1}$ & $\mathbf{1 . 3}$ \\
\hline
\end{tabular}

Table.5 Sepal and Petal size of Dillenia indica

\begin{tabular}{|c|c|c|c|c|}
\hline Flowers & $\begin{array}{l}\text { Petal length } \\
\text { (cm) }\end{array}$ & $\begin{array}{l}\text { Petal breadth } \\
(\mathrm{cm})\end{array}$ & Sepal length $(\mathrm{cm})$ & $\begin{array}{l}\text { Sepal breadth } \\
\text { (cm) }\end{array}$ \\
\hline F-1 & 8.4 & 5.1 & 5.8 & 4.6 \\
\hline F-2 & 8.9 & 5.6 & 5.5 & 3.9 \\
\hline F-3 & 8.8 & 5.9 & 4.9 & 4 \\
\hline F-4 & 8.3 & 4.9 & 5.4 & 4.2 \\
\hline F-5 & 8.3 & 4.8 & 5.5 & 3.8 \\
\hline Mean & 8.54 & 5.26 & 5.42 & 4.1 \\
\hline
\end{tabular}


Table.6 Sepal and Petal size of Spondias mangifera

\begin{tabular}{|c|c|c|c|c|}
\hline Flowers & $\begin{array}{l}\text { Sepal length } \\
(\mathrm{cm})\end{array}$ & $\begin{array}{l}\text { Sepal breadth } \\
(\mathrm{cm})\end{array}$ & Petal length $(\mathrm{cm})$ & $\begin{array}{l}\text { Petal breadth } \\
(\mathrm{cm})\end{array}$ \\
\hline F-1 & 0.1 & 0.09 & 0.3 & 0.2 \\
\hline F-2 & 0.12 & 0.1 & 0.33 & 0.2 \\
\hline F-3 & 0.1 & 0.08 & 0.3 & 0.19 \\
\hline F-4 & 0.1 & 0.09 & 0.3 & 0.2 \\
\hline F-5 & 0.14 & 0.1 & 0.32 & 0.21 \\
\hline Mean & 0.11 & 0.09 & 0.31 & 0.2 \\
\hline
\end{tabular}

Table 7. Sepal size of Flacourtia jangamos

\begin{tabular}{|l|c|c|}
\hline Flowers & Sepal length $\mathbf{( c m )}$ & Sepal breadth $(\mathbf{c m})$ \\
\hline F-1 & 0.2 & $\mathbf{0 . 1 2}$ \\
\hline F-2 & 0.15 & 0.1 \\
\hline F-3 & 0.2 & 0.09 \\
\hline F-4 & $\mathbf{0 . 2 1}$ & 0.1 \\
\hline F-5 & 0.19 & 0.1 \\
\hline Mean & $\mathbf{0 . 1 9}$ & $\mathbf{0 . 1 0}$ \\
\hline
\end{tabular}

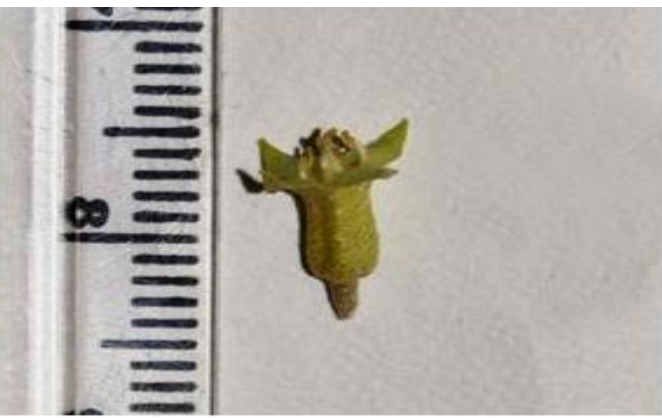

Flower of Parameria polyneura

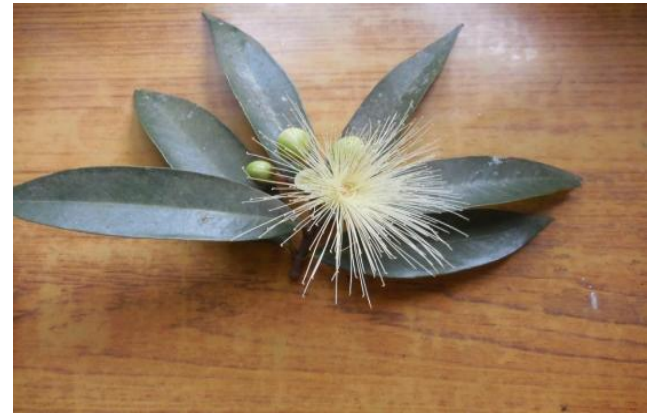

Flower of Syzygium jambos

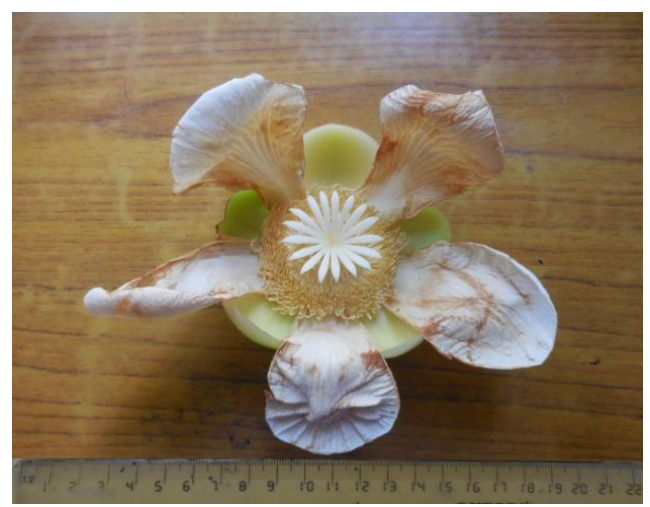

Flower of Dillenia indica 


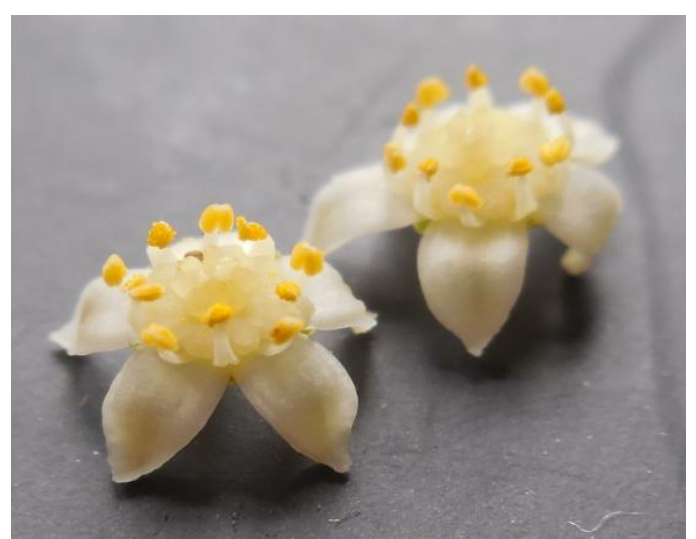

Flower of Spondias mangifera

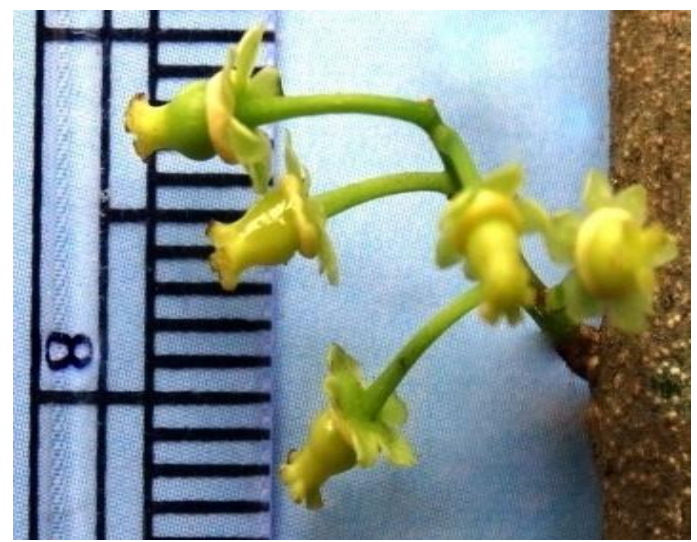

Flowers of Flacourtia jangomas
The sepals of Syzygium jambos were green in colour and somewhat cup shaped and the petals were white to greenish white in colour and were cup shaped. The sepals of Dillenia indica were light green in colour, fleshy, oval to ovate in shape which were somewhat cupshaped and the petals were white in colour, obovate to spathulate in shape. In Spondias mangifera the sepals were whitish green in colour and petals were white in colour, ovate shaped and curved back and in Flacourtia jangamos the shape of the sepal was ovate, yellow to whitish green in colour.

\section{Androecium character}

Under the investigation the androecium character of the flowers of each species were studied. In the flower of Parameria polyneura there were four filaments which were smooth and whitish in colour with anthers attached to them. They were dorsifixed, anthers were pale yellow in colour and were inserted in the tubular portion. In the flower of Syzygium jambos there were numerous filaments which were smooth thread like much longer then the petals whitish in colour with anthers attached to them. Filaments were attached to the anthers at middle i.e. versatile. Anthers were whitish yellow in colour. The flower of Dillenia indica had numerous stamens which were yellow in colour and adnate. Spondias mangifera flower has got 10 numbers of stamen inserted beneath a fleshy disc, filaments are white in colour smooth with one anthers attached to each of the ten filaments, basifixed, anthers are yellowish orange in colour. And in case of Flacourtia jangamos no androecium character was recorded.

\section{Gynoecium character}

Under the investigation the gynoecium character of the flowers of each species were also studied. And according to the data obtained it was found that flower of Parameria polyneura consisted of a style, white in colour attached to an ovary. The ovary was superior. Hence, flower was hypogynous. The style was gynobasic style. There was a long style observed in the flower of Syzygium jambos, white in colour and was attached to the ovary. The ovary was inferior and the style was gynobasic type and flower is said to be epigynous flower. The flower of Dillenia indica had 15-17 carpels. Each carpel consisting of an ovary, stigma and a style, aggregated together to form a flower like structure.

The flower was hypogynous and the ovary was superior. In Spondias mangifera the flower has got a pistil placed over a disc, composed of an ovary and 5 styles. Styles are hypogynous flower. And the flower of Flacourtia jangamos consisted of an ovary 
globose to bottle shaped, yellowish light green colour, superior and 5-6 numbers of style, united, light yellow in colour.

\section{References}

Barua, U. (2015). Morpho-physiological and biochemical characterization of some minor fruits of Assam. Ph.D. (Agri.) Thesis, Assam Agricultural University, Jorhat.

Gopalan, C., Ram Sastri, B.V. and Balasubramaniam, S. C. (1971). Nutritive Value of Indian Foods. Indian Council of Medical Research. New Delhi-16.

Kermash, S., Barthakur, N.N., Mohan, N.K. and Arnold, N.P. (1987). Chemical composition and proposed use of two semi wild tropical fruits. Food Chemistry. 26(4): 972-981.

Neog, M. (1990). Studies on the floral biology, growth and development of few minor fruits of Assam. M.Sc. (Agri.) Thesis, Assam Agricultural University, Jorhat.

Neog, M. and Mohan, N.K. (1993). Physicochemical changes during growth and development of Dillenia (Dillenia indica L.). South Indian Hort. 41(2): 115-116.

Sarma, A. (1989). Studies on the floral biology, growth and development of few minor fruits of Assam. M.Sc. (Agri.) Thesis, Assam Agricultural University, Jorhat.

Sauco, V.G. (2008). Global overview of underutilized tropical and subtropical fruits. Acta Hort. 770: 77-85.

Singh, D., Kumar, K. and Chandel, R.S. (2000). Biodiversity of wild fruits in the Western Himalayas. Asian Agri Histo. 4(3): 233-240.

Tarai, R.K. and Kundu, S. (2008). Flowering behaviour of eight minor fruit crops in new alluvial zone of West Bengal. $J$. Interacad. 12(3): 292-296.

Tarai, R.K., Kundu, S., Ghosh, B. and Mitra, S. (2006). Performance of some minor fruits in West Bengal. Proceedings of National Symposium on Production, Utilization and Export of Underutilized fruits with Commercial Potentialities. $22^{\text {nd }}-24^{\text {th }}$ November, Bidhan Chandra Krishi Viswavidyalaya, West Bengal, pp. 7982.

\section{How to cite this article:}

Nishita Pathak, Rajendra Prasad Das, Utpal Kotoky and Swosti Dedapriya Behera. 2018. Floral Biology of Some Minor Fruits of Assam. Int.J.Curr.Microbiol.App.Sci. 7(07): 1069-1075. doi: https://doi.org/10.20546/ijcmas.2018.707.130 